\title{
Mitochondrial and Peroxisomal Contributions to the Energy Metabolism of Saccharomyces cerevisiae in Continuous Culture
}

\author{
By P. J. ROGERS AND P. R. STEWART* \\ Department of Developmental Biology, Research School of Biological Science, \\ Australian National University, Canberra, A.C.T. 260 I, Australia
}

(Received 30 January I973; revised 4 June 1973)

\begin{abstract}
SUMMARY
Saccharomyces cerevisiae grown in glucose-limited continuous culture at low dissolved oxygen concentrations exhibited high potential respiration rates which reflected the activity of the respiratory enzyme complexes. The development of the mitochondrial respiratory enzymes, unsaturated fatty acids and lipids was highly sensitive to dissolved oxygen even in cells which were growing exclusively by fermentation. A shift to oxidative growth occurred when the oxygen concentration was increased; the apparent oxygen $K_{m}$ for the development of the respiratory complexes was $0.2 \mu \mathrm{M}$. The increase in oxidative metabolism at increased oxygen concentration is related to the development of a functional glyoxylate cycle. Synthesis of the peroxisomal enzymes, including those of the glyoxylate cycle, occurred at significantly higher dissolved oxygen concentration than that of the mitochondrial enzymes.
\end{abstract}

\section{INTRODUCTION}

In the transition from anaerobic to aerobic growth conditions, the yeast mass in cultures of Saccharomyces cerevisiae grown on fermentable sugars increases five to tenfold (Kormancikova, Kovac \& Vidova, I969). In terms of the energetics of yeast-mass production, this is primarily a consequence of the contribution of mitochondrial oxidative phosphorylation to the overall energy economy of the yeast. This increased yeast mass also involves altered biosynthetic patterns, particularly the glyoxylate cycle (Kornberg, I 966). The latter pathway allows the yeast to utilize ethanol, produced in the fermentative stage of growth, to form precursors for cellular components.

In Saccharomyces cerevisiae, the key enzymes of the glyoxylate cycle, isocitrate lyase and malate synthase, are repressed by glucose (Polakis \& Bartley, 1965), and are absent from anaerobically grown yeasts (Duntze, Neumann, Gancedo, Atzpodien \& Holzer, I968); the latter circumstance may also be due to the glucose repression that is inevitable in batchgrown anaerobic cultures (Lowden, Gordon \& Stewart, 1972). Repression of malate synthase by glucose could not be demonstrated by Szabo \& Avers (1969), who reported that malate synthase and isocitrate lyase are located in peroxisomes in yeast cells, and that the activities of enzymes in mitochondria and peroxisomes are independently regulated. They also suggested that the association of glyoxylate shunt and peroxide-metabolizing enzymes in peroxisomes may be related to the involvement of this organelle in gluconeogenesis, and as an oxidase system disposing of NADPH.

The increase of yeast mass that accompanies transition from anaerobic to aerobic growth

* Present address: Department of Biochemistry, School of General Studies, Australian National University, Canberra, A.C.T. 260I, Australia. 
necessarily involves both the energy contribution of mitochondria and the anaplerotic contribution of the glyoxylate cycle of the peroxisomes. It thus seems surprising that these pathways should develop and function independently, as Szabo \& Avers (I969) suggest. However, this question cannot be examined effectively in batch cultures, in which many parameters affecting organelle development are changing with time. Using a glucose-limited chemostat, we have investigated the regulation by oxygen of the synthesis of key enzymes of mitochondria and peroxisomes in Saccharomyces cerevisiae.

\section{METHODS}

Organism and growth conditions. Saccharomyces cerevisiae, a locally isolated diploid strain, was grown in a 41 capacity New Brunswick Microferm at $28{ }^{\circ} \mathrm{C}$ over a range of oxygen concentrations maintained by a dissolved-oxygen controller accessory. Oxygen concentrations were measured with a Mackereth (1964) electrode constructed according to Johnson ( 1967$)$. The nutrient medium contained the following $(\%, \mathrm{w} / \mathrm{v})$ : glucose, 0.3 or $\mathrm{I} \cdot 0$; $\left(\mathrm{NH}_{4}\right)_{2} \mathrm{SO}_{4}, 0 . \mathrm{I} 6 ; \mathrm{NaCl}, 0.05 ; \mathrm{CaCl}_{2}, 0.0 \mathrm{I} ; \mathrm{KH}_{2} \mathrm{PO}_{4}, 0 . \mathrm{I} ; \mathrm{MgSO}_{4} .7 \mathrm{H}_{2} \mathrm{O}, 0.2 ; \mathrm{FeCl}_{3}, 0.0003$; and Difco yeast extract, 0.5 .

Anaerobic conditions of growth were established by gassing the main nutrient reservoir continuously with nitrogen from which residual oxygen had been removed by passage either through a vanadyl sulphate trap (Meites \& Meites, 1948), or over a copper catalyst heated to $150{ }^{\circ} \mathrm{C}$. The nitrogen used was 'oxygen free' grade from Commonwealth Industrial Gases, Sydney, Australia. The nutrient was pumped into a smaller reservoir $(250 \mathrm{ml})$, where it was again flushed with nitrogen. The nutrient then passed into the chemostat by an overflow tube which also carried the nitrogen stream to the fermenter vessel.

Analytical procedures. Procedures for the determination of yeast dry weight in cultures, measurement of potential respiration and cytochromes, assay of enzymes, and extraction and determination of lipids have been described previously (Gordon \& Stewart, I97I; Rogers \& Stewart, 1972). Actual respiration rates of, and carbon dioxide evolution by, cultures in steady state were calculated from differences in concentration of oxygen and carbon dioxide in the input and exit gases. After equilibration of these gases with water, oxygen and carbon dioxide concentrations were measured by means of a YSI oxygen monitor (Yellow Springs Instruments, Ohio, U.S.A.) and a carbon dioxide electrode (Radiometer, Copenhagen, Denmark) connected to a Radiometer model $26 \mathrm{pH}$ meter. The carbon dioxide electrode was standardized with gas mixtures supplied by Commonwealth Industrial Gases. Isocitrate lyase (EC. 4.I.3.I) and malate synthase (EC. 4.I.3.2) were assayed by the methods of Dixon \& Kornberg (I959). Glycolate oxidase (EC. I . I.3.I) was assayed by the method of Feierabend \& Beevers (I972).

Cell-free homogenates. Yeast was harvested by centrifugation after chilling on ice, and disrupted in a Braun MSK homogenizer (Gordon \& Stewart, 197I). From the cell-free homogenate a large-particle fraction corresponding to mitochondria was prepared by centrifuging for $20 \mathrm{~min}$ at $25000 \mathrm{~g}$, and a small-particle fraction was obtained from the remaining supernatant by centrifuging for $90 \mathrm{~min}$ at $100000 \mathrm{~g}$. Both fractions were washed once before resuspending in the homogenization buffer. $(0.9 \mathrm{M}$-sorbitol, $10 \mathrm{~mm}$-tris, $5 \mathrm{~mm}$ EDTA, pH 7·o).

Protein was determined by the method of Lowry, Rosebrough, Farr \& Randall (I95I). Glucose was determined in culture filtrates with the glucostat reagent (Worthington, New Jersey, U.S.A.), and ethanol with a test kit for blood alcohol (Boehringer, Mannheim, Germany). 


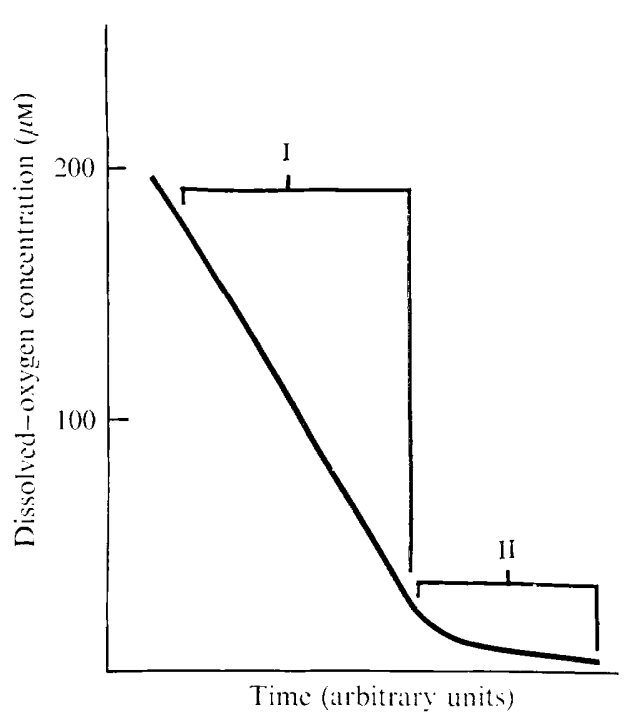

Fig. I

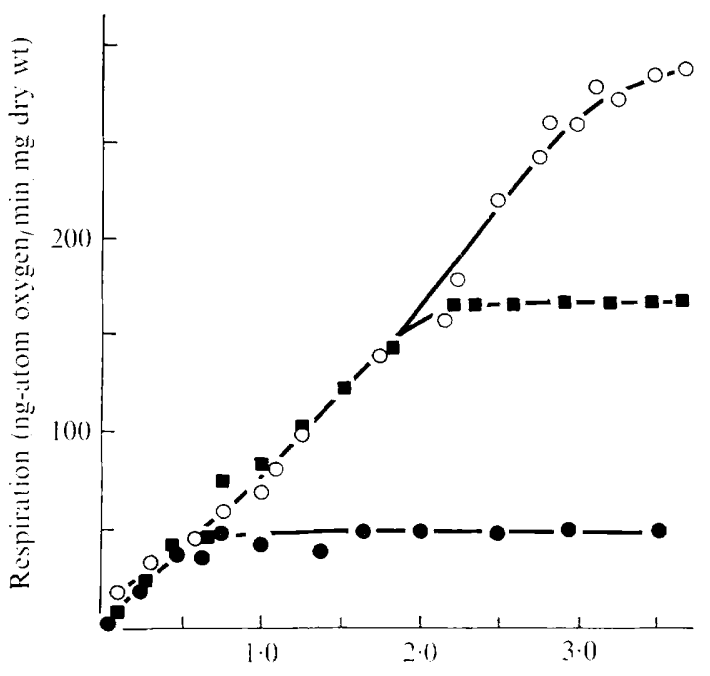

Dissolved-oxygen concentration ( $\mu M)$

Fig. 2

Fig. 1. Oxygen-exhaustion curve recorded when cells were resuspended in air-saturated buffer containing glucose, or when the oxygen supply to continuous cultures of Saccharomyces cerevisiae was elevated to 20 to $30 \mu \mathrm{M}$, then stopped. I, Potential respiration rate is constant and is independent of oxygen concentration. II, Actual respiration rates measured in this region are dependent on oxygen concentration.

Fig. 2. Respiration rates replotted from exhaustion curves (Fig. I), as a function of the dissolvedoxygen concentration for cells cultured at $0.05 \mu \mathrm{M}$-oxygen (O), $0.15 \mu \mathrm{M}$-oxygen ( $\square$ ), and $2.5 \mu \mathrm{M}-$ oxygen (O).

\section{RESULTS}

\section{Effect of oxygen tension on respiratory activity and cell yield}

The chemostat was operated at a dilution rate of $0.07 \mathrm{~h}^{-1}$ (usually over a range of oxygen concentrations of $o$ to $5 \mu \mathrm{M}$ ), which coincided with maximal yeast density in chemostat cultures of this particular organism. At higher dilution rates, effects of glucose repression became evident (Fiechter \& Von Meyenburg, I969), while at lower rates maintenanceenergy requirements became more significant (Leuenberger, I971).

With $15 \mathrm{~mm}$ glucose in the input nutrient, the concentration of glucose in culture filtrates under these conditions was less than $25 \mu \mathrm{M}$. This residual glucose did not change significantly with variation of oxygen concentration in the culture over the range indicated. When steady state was established ( 30 to $40 \mathrm{~h}$ ) a sample of yeast was removed from the chemostat, resuspended in air-saturated buffer, and the respiration rate as a function of oxygen concentration was determined from the exhaustion curves (Figs. I and 2). Alternatively the rate at which the yeast consumed oxygen during steady-state conditions (actual respiration rate) was determined from assays on the gases entering and leaving the culture vessel. Two parameters were obtained from data of the type shown in Figs. I and 2: the maximum or potential respiration rate, and the oxygen concentration required to give half the potential rate, which is referred to as the apparent $K_{m}$ for oxygen. When the steady-state oxygen concentration in the chemostat was increased from $0.02 \mu \mathrm{M}$ to $2.4 \mu \mathrm{M}$, the potential respiration increased from about 50 to $300 \mathrm{ng}$-atom oxygen $/ \mathrm{min} / \mathrm{mg}$ yeast (Fig. 3). Concomitant with this change in potential respiration, the apparent $K_{m}$ for oxygen increased from about 


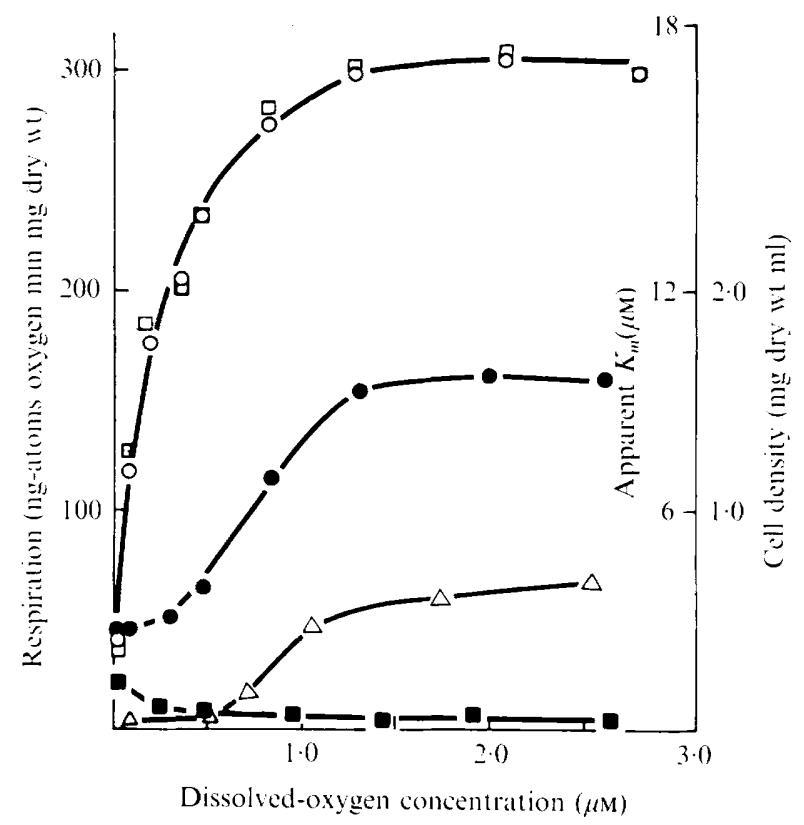

Fig. 3. Cell yield (O), potential respiration rate $(O)$, the cyanide-insensitive portion of the potential respiration ( $\square$ ), actual respiration $(\triangle)$, and apparent $K_{m}$ for oxygen ( $\square$ ), of cells maintained in continuous culture at oxygen concentrations up to $2 \cdot 6 \mu \mathrm{M}$-oxygen.

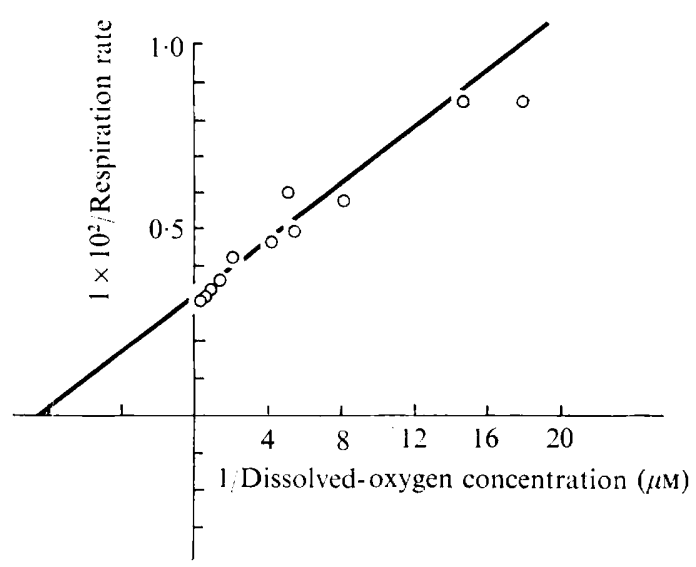

Fig. 4. Double-reciprocal plot of potential respiration rates versus the dissolved-oxygen concentration at which the cells were cultured.

$3 \mu \mathrm{M}$ to $\mathrm{I} 8 \mu \mathrm{M}$, which paralleled almost exactly the increase in potential respiration. However, the actual respiration for each of these cultures, at the oxygen tension prevailing in the chemostat, was very much less than the potential respiration (Fig. 3). The plot of actual respiration is essentially the same shape as the plot of dry weight versus oxygen concentration which is sigmoidal, and shows a half-maximal response at $0.9 \mu \mathrm{M}$-oxygen. A doublereciprocal plot of potential respiration versus oxygen concentration at steady state in the chemostat gives an apparent $K_{m}$ of $0^{\circ} \mathrm{I} \mu \mathrm{M}$ (Fig. 4). The development of high potential rates of respiration is very sensitive to oxygen in the growth media, even though the respiration 
Table I. Yeast yield and respiratory and fermentative parameters for Saccharomyces cerevisiae grown at different dissolved-oxygen concentrations

\begin{tabular}{|c|c|c|c|c|c|c|c|}
\hline $\begin{array}{c}\text { Oxygen } \\
\text { concentrations } \\
(\mu \mathrm{M})\end{array}$ & $\begin{array}{l}\text { Dry wt } \\
(\mathrm{mg} / \mathrm{ml})\end{array}$ & $\begin{array}{c}\text { Yield } \\
\text { (mg dry wt/ } \\
\text { mmole } \\
\text { glucose) }\end{array}$ & $\begin{array}{c}\text { Potential } \\
\text { respiration } \\
\text { (ng-atom O/ } \\
\text { min/mg } \\
\text { dry wt) }\end{array}$ & $\begin{array}{c}Q_{\mathrm{O}_{2}}{ }^{*} \\
\left(\mathrm{ml} \mathrm{O} \mathrm{O}_{2} / \mathrm{g}\right. \\
\text { dry wt/h) }\end{array}$ & $\begin{array}{c}Q_{\mathrm{CO}_{2}} \\
\text { dry } \mathrm{ml} / \mathrm{h})\end{array}$ & $\begin{array}{c}\text { R.Q. } \\
\left(Q_{\mathrm{O}_{2}} / Q_{\mathrm{CO}_{2}}\right)\end{array}$ & $b_{e} \dagger$ \\
\hline Anaerobic & 0.84 & 17 & 50 & - & 106 & - & I. 8 \\
\hline $0.75 \mu \mathrm{M}$ & $2 \cdot 2$ & 44 & 240 & I4 (2I) & 52 & 0.27 & $I \cdot 3$ \\
\hline $\mathrm{I} \cdot \mathrm{O} \mu \mathrm{M}$ & $3 \cdot 1$ & 62 & 280 & $34(52)$ & 45 & 0.75 & 0.58 \\
\hline $2.5 \mu \mathrm{M}$ & 4.4 & 88 & 300 & $40(60)$ & 39 & 0.98 & 0.07 \\
\hline $\mathrm{I} 50 \mu \mathrm{M}$ & $5 \cdot 2$ & 104 & 298 & $44(65)$ & 37 & $1 \cdot 15$ & 0.05 \\
\hline
\end{tabular}

* The figures in parentheses refer to the respiration expressed as ng-atoms oxygen $/ \mathrm{min} / \mathrm{mg}$ dry wt.

$\dagger$ No. of $\mathrm{mol}$ of ethanol produced $/ \mathrm{mol}$ of glucose consumed.

so developed cannot be functioning at near the maximum at the oxygen tensions maintained in the chemostat.

Cyanide-insensitive respiration, which accounted for about one-half of the total respiration of anaerobic yeasts, declined as oxygen tension increased and accounted for only a small fraction of the potential respiration of aerobic yeast (Fig. 3). This cyanide-insensitive respiration was not inhibited by salicyl hydroxamic acid (cf. Lambowitz \& Slayman, I97I).

The oxygen concentration required for half-maximal response of growth yield (approximately $0.9 \mu \mathrm{M}$ ) was markedly different from the corresponding value for potential respiration $(0.12 \mu \mathrm{M})$. Hence, the high potential respiration rates developed at low oxygen concentration in the growth medium were not related to increased efficiency of conversion of culture nutrients to yeast mass. This was also reflected in the ethanol content of culture filtrates (Table I). Under anaerobic conditions ethanol levels in the medium were high, and the yeast yield was low. The number of moles of ethanol produced per mole of glucose consumed $\left(b_{e}\right)$ was $\mathrm{I} \cdot 8$, compared to the theoretical value of 2 . In addition, oxygen consumption could not be detected but carbon dioxide evolution was high, indicating growth by fermentation, and the respiratory quotient $\left(Q_{\mathrm{O}_{2}} / Q_{\mathrm{CO}_{2}}\right)$ was consequently low. As the oxygen concentration was progressively increased to $2.5 \mu \mathrm{M}$ the yeast yield rose to $88 \mathrm{~g} / \mathrm{mol}$ of glucose and the ethanol content of the medium declined to less than I $\mu \mathrm{mol} / \mathrm{mg}$ of yeast. When yeast was equilibrated at an oxygen concentration greater than $2.5 \mu \mathrm{M}$ (up to $150 \mu \mathrm{M}$ ) there was a slight increase in yeast yield to $\mathrm{I} 04 \mathrm{~g} / \mathrm{mol}$ glucose.

Concomitant with an increase in the steady-state dissolved oxygen concentration were a decrease in $\mathrm{CO}_{2}$ evolution and an increase in the oxygen consumption rate; the respiratory quotient increased from 0.3 at $0.7 \mu \mathrm{M}$-oxygen to I $\cdot 0$ at $2.5 \mu \mathrm{M}$-oxygen and I ${ }^{\mathrm{I}} \mathrm{I}$ at $\mathrm{I} 50 \mu \mathrm{M}$ oxygen. There was no further increase in yeast yield or change in cellular respiration or carbon dioxide evolution when the dissolved-oxygen concentration was increased beyond this.

\section{Effect of oxygen tension on fatty acid and ergosterol content of cells}

When Saccharomyces is grown under anaerobic conditions without essential lipid supplements it becomes depleted of unsaturated fatty acids and sterol (Jollow, Kellerman \& Linnane, I968; Gordon \& Stewart, I97I). When aerated, such cells progressively develop mitochondrial function, and at the same time the essential membrane lipids are synthesized 


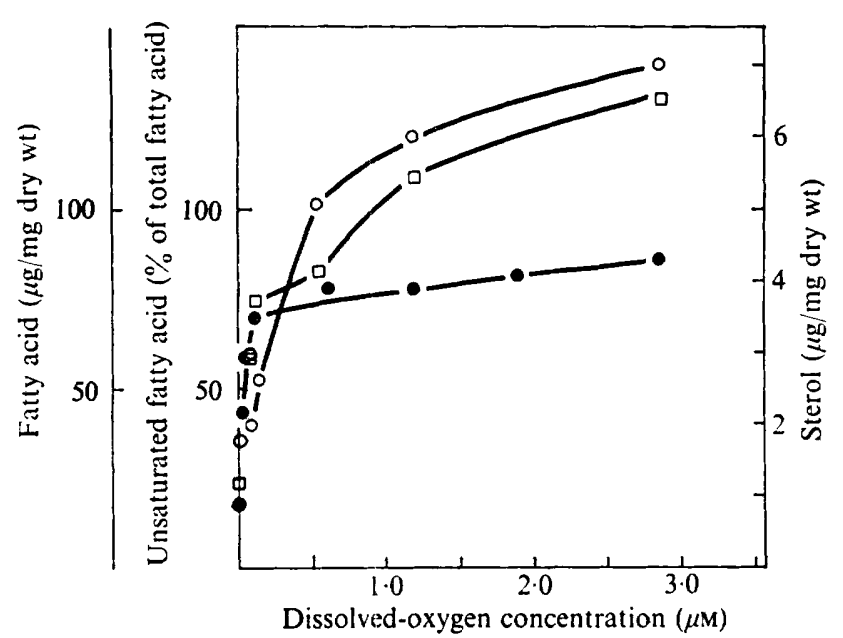

Fig. 5

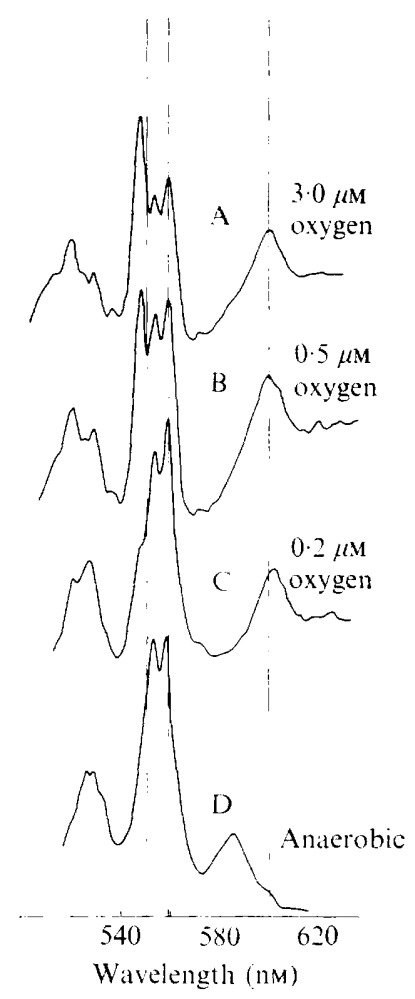

Fig. 6

Fig. 5. Unsaturated fatty-acid content (๑), sterol content ( $\square$ ), and total fatty-acid content (O), of cells grown in continuous culture at oxygen concentrations up to $2 \cdot 8 \mu \mathrm{M}$.

Fig. 6. Reduced versus oxidized difference spectra (at $77^{\circ} \mathrm{K}$ ) of homogenates from cells grown in continuous culture at oxygen concentrations of $3.0 \mu \mathrm{M}(\mathrm{A}), 0.5 \mu \mathrm{m}(\mathrm{B}), 0.2 \mu \mathrm{M}$ (C) and less than $0.05 \mu \mathrm{M}$ oxygen.

(Gordon \& Stewart, 1971 ; 1972). The amounts of these lipids were measured in chemostatgrown yeast because they may be directly relevant to membrane and organelle biogenesis which are related to altered energy metabolism when oxygen tension is changed.

In the most anaerobic condition, unsaturated fatty acids accounted for $18 \%$ of the total fatty acids (Fig. 5). In yeast grown at $2.8 \mu$ M-oxygen, the proportion was $82 \%$, though the major increase occurred at $\mathrm{O} \cdot \mathrm{I} \mu \mathrm{M}$-oxygen. The total fatty acid content increased from 35 to $125 \mathrm{mg} / \mathrm{g}$ of yeast over this range of oxygen concentration, the increase being greatest up to $0.5 \mu \mathrm{M}$-oxygen. The sterol content also increased from near I to almost $7 \mathrm{mg} / \mathrm{g}$ dry wt, with the greatest increase up to approximately $0 \cdot 2 \mu \mathrm{M}$-oxygen.

The levels of unsaturated fatty acids and sterols found in these chemostat-grown cells were thus very sensitive to oxygen. To obtain cells with the low unsaturated fatty acid and sterol content described it was particularly important to deoxygenate completely the nutrient by means of the catalytic technique described in Methods.

\section{Cytochromes of cells and sub-cellular fractions}

Cell-free homogenates from yeast grown at $3.0 \mu \mathrm{M}$-oxygen showed a typical aerobic spectrum (dithionite-reduced minus ferricyanide-oxidized at $77^{\circ} \mathrm{K}$ ) and contained cytochromes 
$a a_{3}, b, c_{1}$ and $c$ ( $\alpha$-absorption maxima at $600,559,553$ and $547 \mathrm{~nm}$ respectively; Fig. 6A). When the oxygen tension in which the cells were grown was decreased to $0.5 \mu \mathrm{M}$ the position of the $\alpha$-bands did not alter, but the amount of cytochrome $c$ decreased in relation to $b$ and $c_{1}$ (Fig. 6B). Identical difference spectra to those described for yeast homogenates were obtained when $25000 \mathrm{~g}$ particles prepared from these yeasts were reduced with succinate in the presence of cyanide and measured against particles oxidized with ferricyanide or persulphate.

Yeasts grown at oxygen concentrations between 0.2 and $0.5 \mu \mathrm{M}$ had an even smaller proportion of cytochrome $c$ (Fig. 6C). When homogenates from this yeast were reduced with dithionite there was no detectable shift in the position of the $\alpha$-bands of cytochromes $b, c_{1}$ or $c$. In the $\beta$-region, however, a band at $526 \mathrm{~nm}$ could be distinguished from the cytochrome $b$ band present at $528 \mathrm{~nm}$, and this probably represents the $\beta$-band of cytochrome $b_{1}$ (Lindenmayer \& Estabrook, 1958 ). When $25000 \mathrm{~g}$ particles from this yeast were reduced with succinate plus cyanide, the spectrum was the same as that described for the homogenate, although the cytochrome $c$ absorption band was relatively decreased, presumably due to loss of cytochrome $c$ from the particles during preparation. Cytochrome $c$ could also be detected in the particle fraction sedimenting between $25000 \mathrm{~g}$ and $100000 \mathrm{~g}$. When the $25000 \mathrm{~g}$ particles from this yeast were reduced with dithionite the $553.5 \mathrm{~nm}$ and $559 \mathrm{~nm}$ peaks were shifted to $55^{2} .5$ and $55^{8} \mathrm{~nm}$ respectively and, in the $\beta$-region, bands were visible at 526 and $530 \mathrm{~nm}$. When the $100000 \mathrm{~g}$ particles were reduced with dithionite, two bands in the $\alpha$-region at 557 and $55 \mathrm{I} \cdot 5 \mathrm{~nm}$ and two bands in the $\beta$-region at 526 and $53 \mathrm{I} \mathrm{nm}$ were seen. These were probably due to cytochrome $b_{1}$ (Lindenmayer \& Estabrook, I958).

Homogenates prepared from anaerobic cells contained bands in the $\alpha$-region at 585,557 and $552 \mathrm{~nm}$, with $\beta$-bands at 53 I, 528 and $526 \mathrm{~nm}$ (Fig. 6D). The $25000 \mathrm{~g}$ particle fraction prepared from this yeast showed two bands at 558.5 and $553 \mathrm{~nm}$ with a small shoulder at $547 \mathrm{~nm}$. There were thus small but measurable amounts of the aerobic cytochromes in the pro-mitochondrial fraction of these cells.

\section{Effect of oxygen tension on the formation of respiratory and glyoxylate-cycle enzymes}

The activities of succinate dehydrogenase, succinate-cytochrome $c$ reductase, fumarase and cytochrome $c$ peroxidase in homogenates were half-maximally induced in yeast grown at $0.2 \mu \mathrm{M}$-oxygen or less (Fig. $7 a$ ). Their formation in the cell was thus closely related to the development of potential respiration (cf. Fig. 3). However, the increase in cytochrome $c$ oxidase activity was less sensitive to oxygen, and this may have reflected the assembly sequence during development of the mitochondrial membrane.

The formation of peroxisomal enzymes responded differently to changes in concentration of environmental oxygen. All showed a sigmoidal response to oxygen concentration in the medium, and were half-maximally induced by $\mathrm{I} \cdot \mathrm{O}$ to $\mathrm{I} \cdot 2 \mu \mathrm{M}$-oxygen (Fig. $7 \mathrm{~b}$ ). Thus there was a marked differential response of mitochondrial and peroxisomal enzymes to oxygen. Moreover, the formation of the peroxisomal enzymes was nearly coincident with the increase in yeast yield in the cultures which occurred in response to increased oxygen concentration (Fig. 3).

\section{Growth on ethanol as carbon source}

The activities of the glyoxylate-cycle enzymes indicated that the peroxisomal system would reach maximal activity at oxygen concentrations in the medium of $\mathrm{I} \cdot 3$ to $\mathrm{I} \cdot 5 \mu \mathrm{M}$. To test whether this system was functional in providing an effective glyoxylate shunt, yeast was grown with ethanol as the carbon source over a range of low oxygen tension (Fig. 8). 


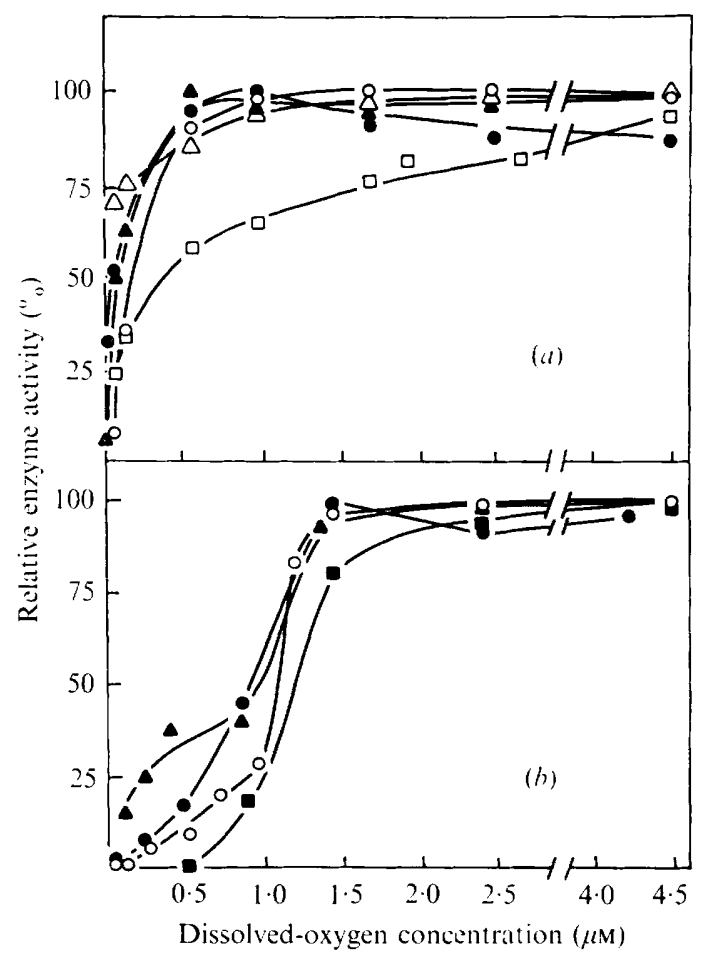

Fig. 7. Activities of $(a)$ mitochondrial and $(b)$ peroxisomal enzymes in homogenates of cells grown at different oxygen concentrations. $(a)$ Cytochrome $c$ peroxidase $(\triangle)$; fumarase $(\bullet)$; cytochrome $c$ oxidase $(\square)$; succinate-cytochrome $c$ reductase $(\boldsymbol{\Delta})$; succinate dehydrogenase $(O)$. $(b)$ Glycolate oxidase $(\mathbf{0})$; malate synthase $(\boldsymbol{\Delta})$; catalase $(0)$; isocitrate lyase $(\boldsymbol{O})$. The specific activities of these enzymes in homogenates of cells grown in $2.4 \mu \mathrm{M}$-oxygen are given in Table 2.

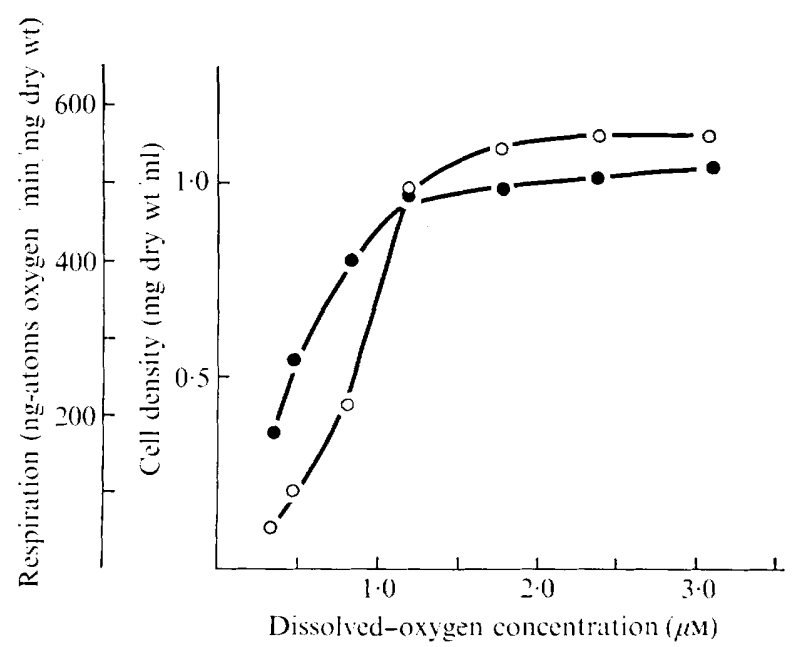

Fig. 8. Cell yield $(\bigcirc)$ and potential respiration $(\bullet)$ of Saccharomyces cerevisiae grown at different oxygen concentrations in continuous culture with ethanol as the carbon source. 
Table 2. Activity of mitochondrial and peroxisomal enzymes in cells grown in $2.5 \mu \mathrm{M}$-oxygen on glucose or ethanol

Cells were grown in chemostats limited for glucose ( $50 \mathrm{~mm}$ in input, $<25 \mu \mathrm{M}$ in culture), or limited for oxygen on ethanol ( $490 \mathrm{mM}$ in input), with the oxygen concentration controlled at $2 \cdot 4 \mu \mathrm{M}$. When steady state had been obtained $(25$ to $35 \mathrm{~h})$ samples were removed, homogenates were prepared by using the Braun homogenizer, and enzyme activities were determined.

Enzyme activity

( $\mu \mathrm{mol} / \mathrm{min} / \mathrm{mg}$ protein)

\begin{tabular}{|c|c|c|c|c|c|c|c|c|}
\hline $\begin{array}{c}\text { Cyto- } \\
\text { chrome } \\
c \\
\text { oxidase }\end{array}$ & $\begin{array}{c}\text { Succinate- } \\
\text { cyto- } \\
\text { chrome } \\
c \\
\text { reductase }\end{array}$ & $\begin{array}{c}\text { Cyto- } \\
\text { chrome } \\
c \\
\text { peroxidase }\end{array}$ & Fumarase & $\begin{array}{c}\text { Succinate } \\
\text { dehydro- } \\
\text { genase }\end{array}$ & Catalase & $\begin{array}{l}\text { Isocitrate } \\
\text { lyase }\end{array}$ & $\begin{array}{c}\text { Malate } \\
\text { synthase }\end{array}$ & $\begin{array}{c}\text { Glycolate } \\
\text { oxidase }\end{array}$ \\
\hline 0.25 & 0.023 & 0.35 & 0.27 & 0.22 & 30 & 0.01 & 0.036 & $I \cdot O$ \\
\hline 0.23 & 0.045 & 0.32 & 0.62 & 0.35 & 35 & 0.045 & 0.04 & 3.5 \\
\hline
\end{tabular}

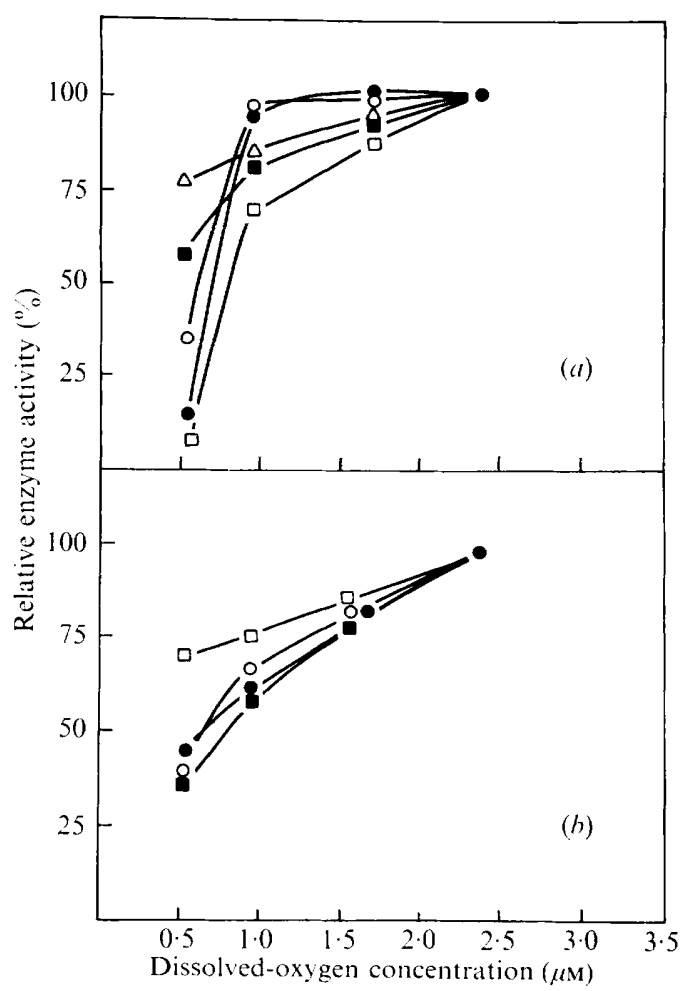

Fig. 9. The activity of some mitochondrial $(a)$ and peroxisomal $(b)$ enzymes in homogenates from cells grown in continuous culture at different oxygen concentrations with ethanol as carbon source.

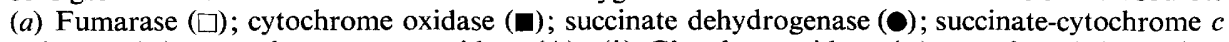
reductase $(O)$; cytochrome $c$ peroxidase $(\triangle)$. (b) Glycolate oxidase $(\boldsymbol{\square})$; catalase $(O)$; malate synthase $(\square)$; isocitrate lyase ( $)$. The specific activities of these enzymes in homogenates of cells grown in $2 \cdot 4 \mu \mathrm{M}$-oxygen are recorded in Table 2 . 
Maximum yeast yield in the chemostat was achieved at $\mathrm{I} \cdot 5 \mu \mathrm{M}$-oxygen; below this value the yeast density was reduced. At the same time, the potential respiration decreased from a maximum of approximately $500 \mathrm{ng}$-atom oxygen $/ \mathrm{min} / \mathrm{mg}$ cells to 160 at $0.35 \mu \mathrm{M}$-oxygen. Wash-out of the cells occurred at oxygen concentrations below $0.35 \mu \mathrm{M}$.

The activities of mitochondrial and peroxisomal enzymes measured in homogenates from either ethanol- or glucose-limited cells maintained at the same oxygen concentration $(2.4 \mu \mathrm{M})$ are shown in Table 2 . Of the mitochondrial enzymes, the activities of cytochrome $c$ oxidase and cytochrome $c$ peroxidase were not significantly different in yeasts from either medium. Fumarase, a mitochondrial-matrix enzyme, and succinate-cytochrome $c$ reductase and succinate dehydrogenase activities were considerably higher in the ethanol-grown yeast, suggesting that some repression existed even at the low concentrations of glucose in the chemostat. The activities of the peroxisomal enzymes, isocitrate lyase and glycolate oxidase were also markedly lower in the glucose-limited cells; however, the activities of catalase and malate synthase were almost identical in homogenates of the yeast from both media.

The effect of decreasing oxygen tension on the activities of the mitochondrial and peroxisomal enzymes in yeasts grown on ethanol is shown in Fig. 9. Again, of the mitochondrial enzymes measured, succinate-cytochrome $c$ reductase, succinate dehydrogenase and fumarase were the most significantly decreased. Likewise, of the peroxisomal enzymes measured, malate synthase was least affected, reflecting the situation seen when glucose was substituted for ethanol as carbon source (Table 2). Significantly, however, the separate development of these two organelles seen in glucose-limited cultures was no longer evident. At oxygen concentrations below $\mathrm{x} \mu \mathrm{M}$, the activities of all enzymes began to decline. This may have reflected a critical concentration of oxygen that was necessary to drive mitochondrial oxidative phosphorylation in vivo. The declining activities of the enzymes may thus reflect effects on protein synthesis as cellular energy pools begin to deplete. It is notable that the oxygen concentration required to support growth of this yeast on non-fermentable substrate is similar to that required for the obligately aerobic yeast Candida utilis (Johnson, I967).

\section{DISCUSSION}

The transition from a non-respiratory mode in continuous cultures of Saccharomyces cerevisiae, limited for glucose, occurred over a very low and narrow range of oxygen concentration.

The transition to oxidative metabolism has been characterized on the basis of the yeast yield, actual oxygen consumption of the steady-state culture, the $Q_{\mathrm{Co}_{2}}$ (specific cellular carbon dioxide release), the respiratory quotient R.Q. $\left(Q_{\mathrm{O}_{2}} / Q_{\mathrm{Co}_{2}}\right)$ and the appearance of ethanol in the culture medium (Table 1 ). During anaerobic growth $b_{e}$ (moles ethanol produced per mole of glucose) was $I \cdot 8$, which was close to the predicted value of 2 , and the R.Q. was low. As the dissolved-oxygen concentration was increased $b_{e}$ declined, the yeast yield increased, and the R.Q. approached the value expected for complete oxidation of glucose.

Cultures grown at oxygen concentrations greater than $2 \mu \mathrm{M}$ were characterized by very low $b_{e}$ values, high yeast yield, and an R.Q. of $\mathrm{I} \cdot 0$, suggesting that the growth of these yeasts was supported by oxidative metabolism.

At low, steady-state concentrations of oxygen the respiration developed was for the most part not used. Thus, the actual respiratory capacity of yeast in the chemostat vessel was very much lower than the potential respiration (measured in the presence of saturating amounts of oxygen); even at the highest concentrations of oxygen employed, actual respiratory rates 
were about one-quarter of potential respiration rates. This was a consequence of the fact that the concentration of oxygen (apparent $K_{m} 0.2$ to $0.5 \mu \mathrm{M}$ ) required to induce the development of the respiratory apparatus of the yeast was much lower than the concentration required to saturate cellular respiration (apparent $K_{m} 3$ to $18 \mu \mathrm{M}$ ).

Yeast respiration expressed as a function of oxygen concentration (calculated from exhaustion curves) reflects either the binding of oxygen to oxidases in the organism (Winzler, I94I), or the diffusion rate of the gas through cell substance (Johnson, I967), or a combination of both processes. The curves shown in Fig. 2 are not 'saturation' curves since they do not yield straight lines when plotted in double-reciprocal form. At low oxygen concentrations, in which respiration increased linearly with increased oxygen concentration, the organism's respiration was apparently a diffusion-limited process (Johnson, 1967). In the regions in which respiration rate was independent of oxygen concentration (i.e. at the potential respiration rate), the concentration of components of the respiratory chain in the yeast was presumably the rate-limiting factor, and this is consistent with the observation that the formation of enzymes of the electron transport system responded to environmental oxygen tension in essentially the same way as did the development of potential respiration (compare Fig. 3 and Fig. $7 a$ ). The actual respiration rate, being much lower, was apparently a diffusion-limited process, controlled mainly by the concentration of oxygen in the culture medium.

It should also be noted that the apparent $K_{m}$ for oxygen-supporting respiration, derived from these data (see Fig. 2 and 3), probably does not reflect changes in the saturation properties of any enzyme or oxygen-carrier systems of the yeast, but is simply an arithmetical consequence of oxygen transport through the yeast being diffusion-limited up to a maximum velocity controlled by the total amount of the oxidase system in the yeast. This is why the potential respiration, and its apparent $K_{m}$ for oxygen, show an identical relationship to environmental oxygen concentration (Fig. 3).

Harrison \& Loveless (197I) have indicated that, under conditions in which growth is energy-limited, the respiration rate $\left(Q_{\mathrm{O}_{2}}\right)$ is related to the respiratory efficiency of the cell $(N)$ thus:

$$
\begin{aligned}
Q_{\mathrm{o}_{2}} & =\frac{\mu}{\mathrm{ATP}}+\frac{M}{N} ; \\
\text { or } Y^{\mathrm{ATP}} & =\frac{\mu}{N Q_{\mathrm{o}_{2}}-M} ;
\end{aligned}
$$

where $Q_{\mathrm{O}_{2}}$ has the units mol oxygen/g organism/h, $\mu=$ specific growth rate $\left(\mathrm{h}^{-1}\right)$ or dilution rate at steady state in the chemostat, $Y^{\mathrm{ATP}}=$ cell yield coefficient for ATP $(\mathrm{g}$ organism $/ \mathrm{mol}$ ATP; Bauchop \& Elsden, 1960), $N=$ mol ATP produced/mol oxygen taken up, and $M=$ maintenance energy $(\mathrm{mol} \mathrm{ATP} / \mathrm{g}$ organism/h) which is the amount of energy required to maintain cells in a viable state in the absence of growth (Harrison \& Loveless, I97I ; Leuenberger, 197I).

Determination of yeast yield per mol of glucose in a series of experiments carried out at low growth rates under aerobic conditions gave values for $M$ of $\mathrm{I} \cdot 6 \times 1 \mathrm{IO}^{-3} \mathrm{~mol} \mathrm{ATP} / \mathrm{g}$ yeast/h. Thus in aerobic yeast (grown in $2.6 \mu \mathrm{M}$ - or $150 \mu \mathrm{M}$-oxygen), $Y^{\mathrm{ATP}}$ values calculated from actual respiration rates are I I I to I $2.6 \mathrm{~g}$ yeast $/ \mathrm{mol}$ ATP. An independent calculation of $Y^{\mathrm{ATP}}$ is possible using yeast yield per mol of glucose. Assuming that under anaerobic conditions $2 \mathrm{~mol}$ of ATP are formed per mol of glucose fermented, then $Y^{\mathrm{ATP}}$ equals $8 \cdot 5$. Under aerobic conditions, however, and assuming $28 \mathrm{~mol} \mathrm{ATP} / \mathrm{mol}$ glucose oxidized, $Y^{\mathrm{ATP}}$ equals $3 \cdot \mathrm{I}$. In these calculations the values used for $Y$ ( $\mathrm{g}$ yeast $/ \mathrm{mol}$ glucose) are 
underestimations since no correction has been applied for glucose utilized for maintenance energy. The true yeast yield, $Y^{\prime}$ may be obtained from the equation (Pirt, 1965):

$$
\frac{\mathrm{I}}{Y}=\frac{M}{\mu}+\frac{\mathrm{I}}{Y^{\prime}}
$$

where $Y$ is the observed yeast yield, $\mu$ is the growth rate $\left(\mathrm{h}^{-1}\right)$ and $M$ is the maintenance energy (mol glucose/g yeast/h); $Y^{\prime}$ may be evaluated by plotting $\mu / Y$ versus $\mu$. For cells grown at I $50 \mu \mathrm{M}$-oxygen, $Y^{\prime}$ is $\mathrm{I} 36 \mathrm{~g}$ yeast $/ \mathrm{mol}$ glucose and hence $Y^{\mathrm{ATP}}$ is $4.9 \mathrm{~g}$ yeast $/ \mathrm{mol}$ ATP. For anaerobic cultures, $Y^{\prime}$ is $2 \mathrm{I}^{\circ} \mathrm{O}$ and $Y^{\mathrm{ATP}}$ is calculated to be 10.5 .

The development of potential respiration is correlated with the appearance in the yeast of the particulate respiratory complexes of the mitochondria, and lipid and cytochrome components of mitochondrial membrane. The formation of succinate dehydrogenase and succinate-cytochrome $c$ reductase is particuarly sensitive to oxygen in the medium, and showed a similar half-maximal response ( $0.25 \mu \mathrm{M}$-oxygen) to that calculated for the development of the potential respiration. The activity of cytochrome oxidase, while at first increasing rapidly as the oxygen tension was raised, was subsequently less responsive to oxygen than succinate dehydrogenase and succinate-cytochrome $c$ reductase, and continued to increase as oxygen concentration was raised to $3.5 \mu \mathrm{M}$. As a reflexion of this differential synthesis of enzymes, the amount of the particulate cytochromes $b$ and $c_{1}$ which are present in the succinate-cytochrome $c$ reductase complex was found to be high compared with cytochromes $a a_{3}$ and $c$ at the more anaerobic conditions tested. Cytochrome $c$ synthesis apparently has the lowest developmental priority of the aerobic cytochromes, being least sensitive in response to increased oxygen tension in the culture medium. This suggests a first priority in mitochondrial membrane development for the tightly bound cytochromes.

The apparent $K_{m}$ for unsaturated fatty acid and sterol synthesis is $0.3 \mu \mathrm{M}$-oxygen or less, and is similar to that for potential respiration. The membrane-bound cytochromes together with unsaturated fatty acids and ergosterol may thus be assembled into functional membrane at low oxygen tension, followed by attachment of the mobile electron carriers ubiquinone and cytochrome $c$ as the oxygen tension rises (Rogers \& Stewart, 1972).

Enzymes associated with the glyoxylate cycle were synthesized at substantially higher oxygen concentrations than that of the mitochondrial enzymes. Most significantly, this corresponds with the point at which ethanol concentration in the medium began to decline rapidly, and yeast yield began to rise. That the increase in yeast yield was related to the development of a functional glyoxylate cycle is shown by the fact that when cells were grown on ethanol, maximum yeast yield occurred at I to $\mathrm{I} \cdot 5 \mu \mathrm{M}$-oxygen, indicating that this was the point at which the anaplerotic function of the glyoxylate cycle was fully developed. The development of peroxisomal function is thus a key event in allowing yeast to exploit more aerobic conditions in its environment.

We are grateful to Professor D. J. Carr for his interest in and encouragement of this work.

\section{REFERENCES}

Bauchop, T. \& ElsdeN, S. R. (1960). The growth of micro-organisms in relation to their energy supply. Journal of General Microbiology 23, 457-469.

Dixon, G. H. \& Kornberg, H. L. (I959). Assay methods for key enzymes of the glyoxylate cycle. Biochemical Journal 72, $3 P$.

Duntze, W., Neumann, D., Gancedo, J. M., Atzpodien, W. \& Holzer, H. (1968). Studies on the regulation and localization of the glyoxylate cycle enzymes in Saccharomyces cerevisiae. European Journal of Biochemistry 10, 83-89. 
Feierabend, J. \& Beevers, H. (1972). Developmental studies on microbodies in wheat leaves. I. Conditions influencing enzyme development. Plant Physiology 49, 28-32.

Fiechter, A. \& Von MeyenburG, H. K. (I969). Regulatory properties of growing cell populations of Saccharomyces cerevisiae in a continuous culture system. In Yeasts, pp. 387-398. Edited by A. KockovaKratochvilova. Bratislava: Slovak Academy of Sciences.

Gordon, P. A. \& Stewart, P. R. (I97I). The effect of antibiotics on lipid synthesis during respiratory development in Saccharomyces cerevisiae. Microbios 4, I I 5-I 32.

Gordon, P. A. \& Stewart, P. R. (I972). Effect of lipid status on cytoplasmic and mitochondrial protein synthesis in anaerobic cultures of Saccharomyces cerevisiae. Journal of General Microbiology 72, $23 \mathrm{I}-24 \mathrm{I}$.

HARrison, D. E. F. \& Loveless, J. E. (I97I). The effect of growth conditions on respiratory activity and growth efficiency in facultative anaerobes grown in chemostat culture. Journal of General Microbiology 68, 35-43.

Johnson, M. J. (1967). Aerobic microbial growth at low oxygen concentrations. Journal of Bacteriology 94 , IOI-IO8.

Jollow, D., Kellerman, G. M. \& Linnane, A. W. (I968). The biogenesis of mitochondria. III. The lipid composition of aerobically and anaerobically grown Saccharomyces cerevisiae related to the membrane systems of the cells. Journal of Cell Biology 37, 221-230.

Kormancikova, V., Kovac, L. \& Vidova, M. (1969). Phosphorylation efficiencies in growing cells determined from molar growth yields. Biochimica et biophysica acta $\mathbf{1 8 0}$, 9-17.

KornberG, H. G. (1966). Anaplerotic sequences and their role in metabolism. Essays in Biochemistry 2, I-32.

Lambowitz, A. M. \& Slayman, C. W. (1971). Cyanide-resistant respiration in Neurospora crassa. Journal of Bacteriology 108, 1087-1096.

LeUenberger, H. G. W. (197I). Cultivation of Saccharomyces cerevisiae in continuous culture. I. Growth kinetics of a respiratory deficient yeast strain grown in continuous culture. Archiv für Mikrobiologie 79, $176-186$.

LindenMayer, A. \& Estabrook, R. W. (1958). Low-temperature spectral studies on the biosynthesis of cytochromes in baker's yeast. Archives of Biochemistry and Biophysics 78, 66-82.

Lowden, M. J., Gordon, P. A. \& Stewart, P. R. (1972). Regulations of the synthesis of mitochondrial enzymes and cytochromes: distinction between catabolite repression and anaerobiosis in Saccharomyces cerevisiae. Archiv für Mikrobiologie 85, 355-36I.

Lowry, O. H., Rosebrough, E. J., Farr, A. L. \& Randall, R. J. (I95I). Protein measurement with the Folin phenol reagent. Journal of Biological Chemistry 193, 265-275.

MACKERETH, F. J. H. (I964). An improved galvanic cell for determination of oxygen concentration in fluids. Journal of Scientific Instrumentation 4r, 38-4I.

Meites, L. \& Meites, T. (i948). Removal of oxygen from gas streams. Analytical Chemistry 20, 984-985.

PIRT, S. J. (1965). The maintenance energy of bacteria in growing cultures. Proceedings of the Royal Society, B I63, 224-23I.

Polakis, E. S. \& Bartley, W. (1965). Changes in the enzyme activities of Saccharomyces cerevisiae during aerobic growth on different carbon sources. Biochemical Journal 97, 284-297.

Rogers, P. J. \& Stewart, P. R. (1972). Respiratory development in Saccharomyces cerevisiae grown at controlled oxygen tension. Journal of Bacteriology $\mathbf{1 1 5}, 88-97$.

SzaBo, A. S. \& Avers, C. J. (I969). Some aspects of regulation of peroxisomes and mitochondria in yeast. Annals of the New York Academy of Sciences 168, 302-31 2.

WINZLER, R. J. (I94I). The respiration of baker's yeast at low oxygen tension. Journal of Cellular and Comparative Physiology 17, 263-276. 